\title{
A three-century storm climatology for Dublin 1715-2000
}

\author{
John Sweeney \\ Department of Geography, National University of Ireland, Maynooth
}

\begin{abstract}
A need to quantify better the hazard posed by storms in Ireland exists, particularly during a time of imminent climate change. To assist this, a rudimentary storm chronology for the Dublin region was constructed for the period 17152000 using documentary and instrumental records. The former, using early newspapers and other weather catalogues, indicates a period of marked storm activity in the early eighteenth century which corresponds to the later stages of the Little Ice Age in Ireland. Instrumental records, though also imperfect, suggest that the twentieth century had a number of stormy intervals, particularly in the 1920s, 1960s and early 1990s. These were probably comparable to the early eighteenth century in storm frequency and severity. A clear link between storm frequency and cyclonic synoptic circulation types was established, with stormy decades evident at times of high frequencies of Jenkinson-Lamb cyclonic types. Preliminary analysis of some of the most severe storms indicated that rapid deepening of sometimes quite small wave depressions close to Ireland are the most common occurrence, though this may not have been so in the past. An expectation of increases in storm activity in the vicinity of Ireland exists for the medium term as global warming proceeds, though in the longer term a decline in vigour of the westerly circulation can be anticipated.
\end{abstract}

Key index words: storms, Ireland, documentary sources, instrumental records.

\section{Introduction}

Wind is undoubtedly the most feared natural hazard in Ireland, and past severe storms occupy a special place in the public consciousness. The lrish language has a rich variety of descriptors for wind hazards, perhaps inevitable in a country where the relatively frictionless surface of the sea is everywhere within a few tens of kilometres and where Atlantic depressions are frequently close to their most mature state as they pass overhead. It is not surprising therefore that storms generate a rich source of references in early manuscripts and writings in a country which has one of the longest documentary traditions in the western world.

The frequency and severity of storm events is of major economic concern. This is because of the damage that can be done to structures such as bridges and buildings, forests, crops and communications as well as the disruption which storms can cause to activities such as transport, power supply and the impact they may have on the coastline (Lozano, 1999). In Britain, the 'Great Storm' of $16^{\text {th }}$ October 1987, which traversed south-east England, caused over $£ 2000 \mathrm{M}$ of damage (at current prices) and marked the start of a ten-year period when weather-related hazards would cost the British insurance industry $£ 10 \mathrm{~B}$. In recent years in Ireland, a growing appreciation of the economic cost of individual events is also apparent. The Christmas Eve storm of 1997 generated 47,500 insurance claims totalling $£ 45 \mathrm{M}$ while the St Stephen's Day storm of 1998 is estimated to have cost the industry in excess of $£ 100 \mathrm{M}$ (Irish Insurance Federation, 1999). 
Of immediate concern for risk calculations, and thus for premium loadings for the insurance industry, and for major civil engineering works, is whether the frequency, and therefore return periods, of severe storms is altering, or is likely to alter, as global climate changes occur in the immediate future. The picture is as yet not clear in this area. Some studies show no dramatic changes occurring, with fluctuations in storm incidence only what would be expected within the natural boundaries of the existing climate system (Hammond, 1990). There is a suggestion from storm records elsewhere in Europe though that an increased incidence of storm activity in the eastern Atlantic can be detected since the 1950s (Lamb, 1991). This appears to correlate well with similar changes in the North Atlantic Oscillation (Hurrell, 1995). In an analysis of very deep depressions, with central pressures less than or equal to $900 \mathrm{hPa}$ in the Atlantic, Schinke (1993) identified a marked increase in frequency over the period 1930-91. Perhaps by way of corroboration, German naval observations suggest that the frequency of wave heights over $4-5 \mathrm{~m}$ in the North Sea appears to have increased by $50-100$ percent since the 1950s (Lamb and Weiss, 1979) while Gulev and Hasse (1999) report an increase in significant wave height averaging $10-30 \mathrm{~cm} /$ decade over the whole North Atlantic since the 1960s. A more recent study by Page (1997) involved the digitising of 2400 depressions crossing the Greenwich meridian from 1869 onwards and also showed a rising trend in the number of intense depressions counted, particularly during the late 1980 s and early 1990 s. However, since the early 1990 s there is an indication of a return to conditions more typical of the century in general.

Some of these changes in frequency may be linked to wider scale circulation changes associated with global warming. The Intergovernmental Panel on Climate Change (Mitchell et al., 1992) suggest that in a world where the pole-equator temperature gradient is reduced, the vigour and variability of the Atlantic storm should also reduce somewhat. However local conditions, such as associated changes in sea-ice and sea surface temperature, may be sufficient to negate this tendency in the medium term. A recent Hadley Centre global climate model run (HADCM2) implies that winter storm frequencies and intensities in the vicinity of Ireland would be expected to increase as global warming proceeds (Murphy et al., 1995).

It is clear, however, that any attempts to estimate the likelihood of future severe storm frequencies in Ireland must be based on quantification of the frequency and severity of past events. This necessitates a survey of as long a period for which reliable data can be obtained in order to provide a yardstick for the future. This paper attempts to achieve this through an analysis of storm activity in the Dublin region from 1715 to the commencement of the year 2000. The climatology derived is representative of conditions in the Dublin region, and possibly much of eastern Ireland, over that period though should not be considered representative of areas further west where a significantly windier regime exists.

\section{Wind Regime of the Dublin Region}

As with all parts of Ireland, the Dublin region experiences a prevailing wind from the south and west, though this can be overemphasised, and winds from all quadrants except north and east are generally well represented in the annual wind rose. Westerlies are more frequent during the summer, though their strength is considerably less than in the winter months. The summer displacement northward of the Azores High and the seasonal heating up of the European landmass tends to sharpen the west to east pressure gradient over Ireland at this time, though the vigour of disturbances embedded in the westerlies is much reduced. This 
is as a consequence of the diminution of the polar-tropical thermal contrast, which drives the upper westerlies, as the seasonal displacement of maximum solar heating migrates well into the Northern Hemisphere and as longer hours of daylight at higher latitudes inhibit cooling. A diurnal variation in mean wind speeds also exists in most parts of Ireland with nocturnal speeds typically 2-4 knots (1-2m/s) less than those of early afternoon.

Directional frequencies are often affected by nearby uplands, and this can on occasion be clearly seen at Dublin Airport where funnelling of the wind occurs around the Wicklow Mountains, which lie to the south (Figure 1). The aerodynamic roughness of the city itself (which also lies south of the synoptic station) is a further factor. The purpose of this is to emphasise that observations of wind speed at given points may not be representative of conditions in their hinterland and that a more extreme wind climate may be experienced at localised scales with wind trajectories from particular directions.

Gales, defined as a period of not less than ten minutes during which mean wind speed exceeds 34 knots $(17.5 \mathrm{~m} / \mathrm{s})$, are experienced on about eight days per year in the Dublin

\section{Dublin Airport}

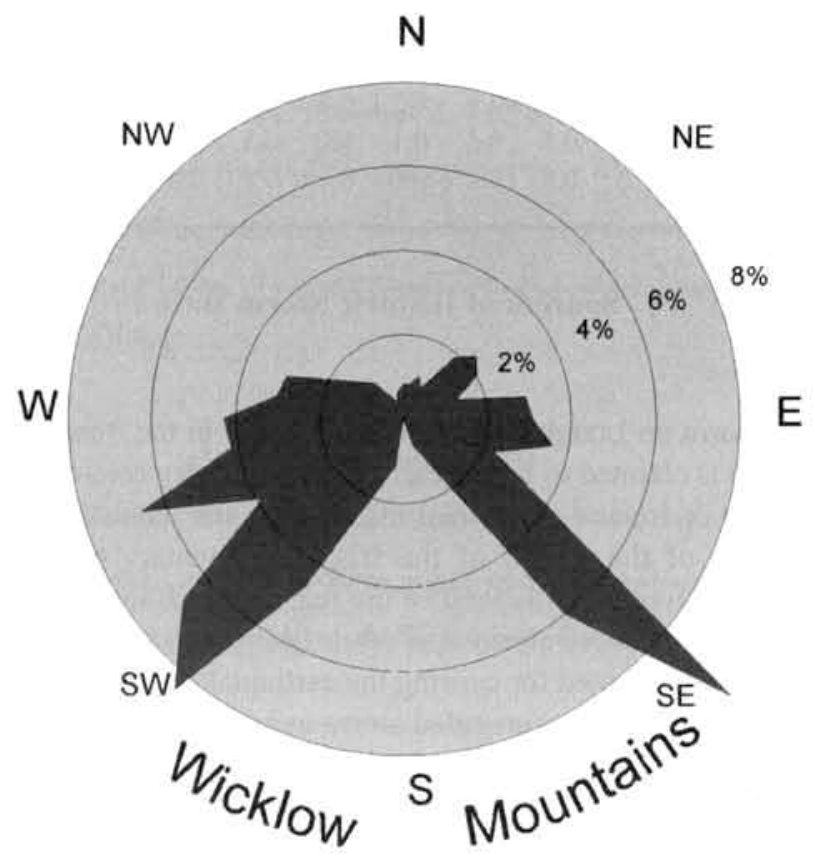

Calm: $0.1 \%$

$\begin{array}{lllll}0 & 1 & 2 & 3 & 4 \%\end{array}$

Figure 1: A wind rose for Dublin airport for July 1995 showing the sheltering effect of the Wicklow mountains which are south of the city.

region. This is in stark contrast to the north and west of Ireland where over 60 days per year record gales at some locations (Table 1). Gusts are reported at wind observing stations when 
the wind speed in the gust exceeds the mean wind speed being observed by more than 10 knots $(5 \mathrm{~m} / \mathrm{s})$. It is the strongest gusts which do most damage in a storm and Table 1 also shows that most coastal locations in Ireland have experienced gusts of $90-100$ knots (46$51 \mathrm{~m} / \mathrm{s}$ ) during the standard 30 year period of records.

Table 1: Average number of gale days per month from 1961-90 and highest gusts observed.

\begin{tabular}{lrlllllllllllll}
\hline Location & J & F & M & A & M & J & J & A & S & O & N & D & Year & $\begin{array}{r}\text { Max } \\
\text { Gust }\end{array}$ \\
\hline Belmullet & 5.5 & 4.2 & 3.3 & 1.1 & 1.0 & 0.4 & 0.3 & 0.8 & 2.3 & 3.6 & 3.4 & 4.5 & 30.5 & 93 \\
Birr & 0.4 & 0.4 & 0.1 & 0.0 & 0.0 & 0.0 & 0.0 & 0.0 & 0.0 & 0.1 & 0.0 & 0.2 & 1.2 & 85 \\
Casement & 5.2 & 2.7 & 2.7 & 0.6 & 0.5 & 0.1 & 0.1 & 0.2 & 0.6 & 1.4 & 2.4 & 3.7 & 20.3 & 81 \\
Claremorris & 1.2 & 0.9 & 1.0 & 0.1 & 0.1 & 0.1 & 0.0 & 0.0 & 0.2 & 0.4 & 0.5 & 0.7 & 5.2 & 96 \\
Clones & 1.2 & 0.8 & 0.9 & 0.2 & 0.2 & 0.1 & 0.0 & 0.0 & 0.2 & 0.3 & 0.3 & 0.5 & 4.8 & 87 \\
Cork A/P & 3.2 & 2.2 & 1.7 & 0.7 & 0.4 & 0.1 & 0.1 & 0.2 & 0.7 & 1.2 & 1.8 & 2.5 & 15.0 & 94 \\
Dublin A/P & 2.1 & 1.1 & 1.2 & 0.3 & 0.3 & 0.1 & 0.0 & 0.3 & 0.2 & 0.5 & 0.7 & 1.4 & 8.2 & 75 \\
Kilkenny & 0.5 & 0.3 & 0.1 & 0.0 & 0.0 & 0.0 & 0.0 & 0.0 & 0.0 & 0.1 & 0.1 & 0.3 & 1.4 & 77 \\
Malin Head & 11.2 & 8.6 & 8.0 & 3.4 & 2.3 & 1.3 & 0.8 & 1.5 & 3.8 & 6.7 & 8.7 & 9.7 & 66.0 & 98 \\
Mullingar & 0.7 & 0.6 & 0.2 & 0.1 & 0.1 & 0.0 & 0.0 & 0.0 & 0.1 & 0.2 & 0.2 & 0.3 & 2.5 & 79 \\
Roche's Pt & 6.0 & 4.4 & 4.2 & 1.8 & 1.5 & 0.3 & 0.5 & 0.9 & 1.8 & 3.1 & 3.5 & 5.3 & 33.3 & 86 \\
Rosslare & 2.5 & 1.5 & 1.1 & 1.3 & 0.3 & 0.2 & 0.1 & 0.2 & 0.5 & 0.9 & 1.3 & 1.9 & 11.7 & 87 \\
Shannon A/P & 2.1 & 1.2 & 1.4 & 0.5 & 0.5 & 0.1 & 0.0 & 0.1 & 0.6 & 0.9 & 1.0 & 1.5 & 9.8 & 93 \\
Valentia & 2.5 & 2.0 & 1.3 & 0.3 & 0.4 & 0.0 & 0.0 & 0.1 & 0.5 & 0.8 & 1.5 & 1.8 & 11.2 & 88 \\
& & & & & & & & & & & & & & \\
\hline
\end{tabular}

\section{Sources of Historic Storm Data}

\section{Documentary References}

Reference to a storm on Lough Conn in county Mayo in the Annals of the Four Masters in $2668 \mathrm{BC}$ (Figure 2) is claimed to be the earliest documentary reference to a meteorological event in either Britain or Ireland (Britton, 1937). While the date is of dubious veracity, the reference is indicative of the length of the Irish documentary tradition and also of the importance of storms in everyday life, and of the fear in which they were held. Indeed while in more recent centuries a severe storm was often deemed to be an 'Act of God', until the Middle Ages the devil was blamed for causing the earthquakes which it was believed initiated severe gales. Many of the early documented storm events in Ireland were collated by Wilde (1851) for the census of that year and the chronology he established was further elaborated for the Dublin area by Dixon (1959) though inevitably the record of early events is extremely sketchy.

The later Annals are more informative concerning damage and places affected so that particular instances of storm events in eastern Ireland may be isolated. Dixon (1959) presents an excellent compilation of the highlights, from which the extracts below were obtained. Medieval events such as St Maury's wind of $15^{\text {th }}$ January 1362 for example are recorded as:

"a vehement wind which shook and threw to the ground the steeples, chimneys and other higher buildings, trees beyond number and divers belfries and the bell tower of the Friars' Preachers in Dublin." 


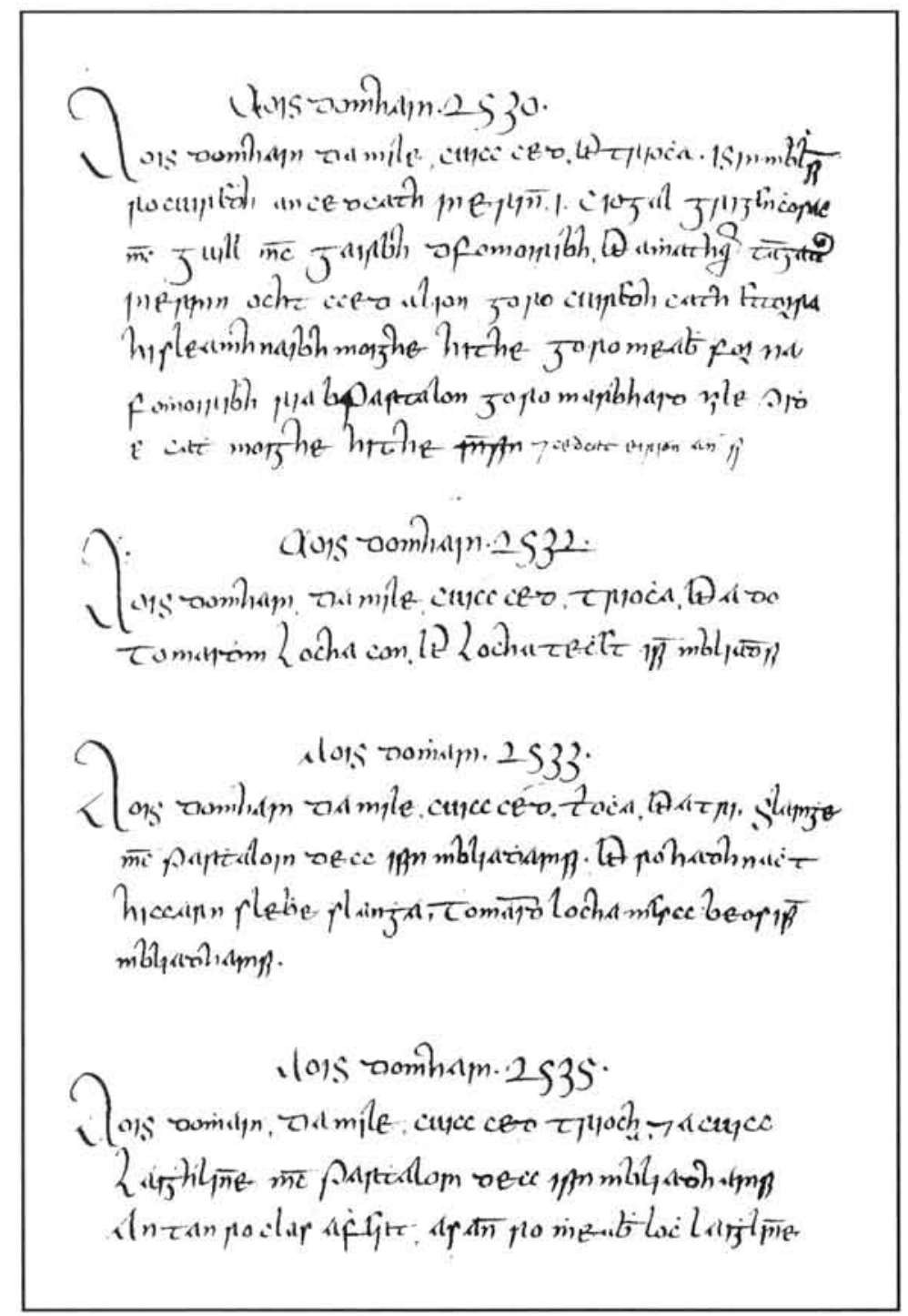

Figure 2: A storm on Lough Conn in 2668 BC from the Annals of the Four Masters.

So seriously was the storm hazard taken that the town crier of Dublin was designated as a gale warning facility and the records of the city for 1577 decreed that:

"a bell shalbe knolled in tyme of greate tempest and storms, to thend that every well disposed cittizen may be remembred to pray for ther neighbors which be in danger uppon the seas, and that Mr Mayor and aldermen shall take order what allowance or rewarde shalbe given to hym that shall take payne in knoling of the said bell."

Later in the sixteenth century there are relatively few reports of storm damage, even for the famous 'Armada Storm' of 1588 when it would appear that the wrecking of many Spanish ships on the Irish coastline was as much due to cartographic errors as to the storm per se. Much of the seventeenth century also appears to have been relatively quiescent. The most 
notable events appear to have occurred in Dublin in February 1668, November 1674 and in November 1696 when the packet-boat William was wrecked on the north side of Dublin Bay with the loss of over 80 people.

The major storm in Britain of 7-8 th December (new calendar) 1703, the subject of Daniel Defoe's The Storm, was probably the most severe event for parts of Britain for the last 300 years and contributed to the death of several thousand people. Lamb (1991) cites reports that on that night one-third of all the seamen in the navy, some 10,000 men, were lost. The storm does, however, appear to have left eastern Ireland relatively unscathed with only slight references to the collapse of part of the Dublin city wall and damage to a malthouse and kiln in the city centre (Dixon, 1959). By the eighteenth century, however, more complete coverage of events and the beginnings of newspaper reports and good weather diaries help build a better picture of individual events. Rutty (1772) documented 100 storms between 1716 and 1765 , an average of two per year in what seems to have been a particularly stormy period. The documentary record also suggests that the early nineteenth century was unusually stormy. The $19^{\text {th }}$ November 1807 saw the wrecking of two troopships, Prince of Wales and Rochdale, in a north-easterly blizzard between Dublin and Kingstown (Dun Laoghaire).

It was at the end of the 1830 s that probably the major storm of the past 300 years occurred. The events of the $6^{\text {th }}$ January 1839 affected the north side of Dublin most severely, though no part of the city escaped unscathed. Some 20-25 percent of all houses in Dublin suffered damage in 'The Night of the Big Wind' as a depression probably as deep as $918 \mathrm{hPa}$ tracked eastwards to the north of Ireland (Shields and Fitzgerald, 1989). Scaling up damage costs to present-day values would suggest a bill well in excess of $£ 200 \mathrm{M}$, not taking into account the increase in property values which has occurred in the interim. A repeat of this storm is considered to be the 'worst case scenario' for insurance purposes in Ireland. The storm came at a time when a rudimentary instrumental network of meteorological stations was being established across Britain and Ireland, enabling objective rather than subjective data to become available.

\section{Instrumental Records}

Although a weather registry existed in Trinity College in the $1680 \mathrm{~s}$, it was not until a century later in 1780 that Richard Kirwan started the first Irish meteorological station from which reliable readings were to emerge. This was at Cavendish Row in Dublin. Kirwan maintained the observations until his death in 1812 by which time regular meteorological observations had commenced at the Botanic Gardens (in 1800). These, and a subsequent station at the Ordnance Survey offices in the Phoenix Park (1829), have continued uninterrupted since then. However despite an ingenious rudimentary instrument devised by Kirwan, wind observations were not satisfactory until Thomas Robinson invented the cup anemometer in 1846, possibly in response to the major Irish storm of 1839 (Dixon, 1959). The first two instruments to be deployed in the Dublin area were placed at Dunsink Observatory and on the East Pier at Kingstown (Dun Laoghaire) in 1852 where the original instrument was still functioning over a century later.

Two synoptic stations currently collect wind data in the Dublin area: Dublin Airport to the north of the city and Casement Aerodrome to the west. Both stations employ a Dines Pressure-Tube instrument. Since this instrument responds quickly to changes in wind speed, it tends to records gusts 6-7 percent higher on average than those measured using a rotating cup anemometer. The latter by comparison tends to overestimate mean wind speeds in gusty 
conditions due to freewheeling (Linacre, 1992). The Dublin Airport instrument is located at a height of 12 metres above the surface of the station, 2 metres higher than that required by World Meteorological Organisation regulations. To augment the Dublin Airport observations for the period before 1941, data from the Robinson Cup anemometer located on Dun Laoghaire Pier were also utilised. This provided data from 1903 (earlier records were unreliable), though obviously posed difficulties of comparability with the Airport data which are discussed later.

\section{Methodology}

Since a mixture of early meteorological observations and documentary sources exists for storm events in the Dublin region, a two-strand approach to the construction of a storm chronology was adopted:

A database of severe storm events from 1715-1999 was derived from documentary reports and newspaper coverage, and

A database of severe storm occurrences from 1903-1999 was derived using standard meteorological observations from stations in the Dublin region.

From $1^{\text {st }}$ January 2000 back to 1860 the principal newspaper source used was the Irish Times, a national daily with the bulk of its circulation in the Dublin area. Each daily issue was consulted. Prior to 1860 two earlier newspapers were utilised: the Freeman's Journal and the Dublin Evening Post. The Freeman's Journal extended back to 1763, with the Dublin Evening Post providing a patchy record commencing in 1719. For the later parts of the documentary record which overlapped with the instrumental period, cross references were made to the daily weather and monthly wind summaries contained in the Monthly Weather Report of Met Éireann and a judgement made concerning the reliability of the newspaper report concerned. For inclusion in the record, the report concerned had to relate to damaging events in the Dublin region and reports of severe Atlantic storms or storms in western Ireland were discounted. It must be acknowledged, however, that cross referencing was often not possible for the earlier parts of the record, other than by consulting existing chronologies such as Rutty (1772), Wilde (1851), Dixon (1959) or Lamb (1991). Despite every effort at selection consistency, subjectivity undoubtedly remains a problem and the methodological difficulties posed in employing newspaper sources cannot be over emphasised.

While undoubtedly they constitute a valuable source of information about the effects of storms and their seasonal occurrence, great caution must be exercised in the use of data derived from newspapers concerning severity. Writers excel in superlatives, particularly in older newspapers, and there is an over use of phrases such as "the greatest storm in living memory" or similar. Phraseology does tend to differ, though, when exceptional events occur, as do other variables such as the amount of space devoted to the storm, the prominence it gets, and for how long it remains news. Of course, these variables themselves are in turn often dependent on what the other news priorities are. There are also limitations to the amount of damage that can be reported which may relate to the reporting network of the newspaper concerned. During the early part of the record, for example, many currently built-up parts of Dublin city were relatively isolated rural settlements and the extent of storm damage would not have figured as prominently as would events closer to where the newspaper offices were located. Over a lengthy period, the spatial coverage of a newspaper may vary according to its target readership. Restrictions on reporting during wartime also have to be borne in mind as does the social class make-up of the readership. Especially in the earlier parts of the record 
this was often middle and upper class dominated and certainly influenced the nature of the storm reports. Thus while the destruction of suburban ornamental trees may have figured prominently in some reports, the storm event concerned may have been particularly severe in poorer districts where its effects went unreported or under reported.

\section{Storms: the Documentary Record}

Examination of the various sources produced a database amounting to 578 storms over the 285 year period. This is an average of 2.03 events per year. Inevitably some events may not have been reported, some may have been exaggerated, and for some periods, especially in the early years, patchy reportage exists. Notwithstanding these difficulties, the frequency is almost identical to Rutty's (1772) figure of 100 storms between 1716 and 1765 and very close to the average figure which can be derived from the recent instrumental record of 1.87 storms per annum.

Table 2: Monthly/Decadal storm frequencies at Dublin from documentary sources 1715-1999.

\begin{tabular}{|c|c|c|c|c|c|c|c|c|c|c|c|c|}
\hline & Jan & Feb & Mar & Apr & May & Jun & Jul & Aug & Sep & Oct & Nov & Dec \\
\hline $1715-19$ & & 2 & & & & & & 1 & 1 & 2 & & \\
\hline $1720-29$ & 2 & 2 & 2 & 1 & 1 & & 2 & & & 1 & 7 & 6 \\
\hline $1730-39$ & 5 & 3 & & 1 & & & 1 & & 2 & & & 6 \\
\hline $1740-49$ & 7 & 5 & & 1 & & 1 & 1 & 3 & 4 & 6 & 5 & 5 \\
\hline $1750-59$ & 3 & 6 & 3 & & & & & & 1 & 1 & 2 & \\
\hline $1760-69$ & 3 & 1 & 2 & 1 & & & & & 3 & 5 & 4 & 7 \\
\hline $1770-79$ & 1 & & & & & & & & & & & \\
\hline $1780-89$ & & & & & & & & & 1 & & & 1 \\
\hline $1790-99$ & 5 & 3 & 2 & 1 & & & & & & 3 & 2 & 5 \\
\hline $1800-09$ & 6 & 1 & & & & & & & & & & 4 \\
\hline $1810-19$ & & & & & & & & & & & & 1 \\
\hline $1820-29$ & & & & & & & & & & & & 3 \\
\hline $1830-39$ & 1 & & 1 & & & & 1 & & & 1 & 1 & \\
\hline $1840-49$ & 3 & & & & 1 & & 1 & & & & 3 & 3 \\
\hline $1850-59$ & & 1 & & 1 & & & & & & & & 2 \\
\hline $1860-69$ & & 1 & & & & & & & & & & \\
\hline $1870-79$ & 1 & & & & & & & & & & & \\
\hline $1880-89$ & & & & & & & & & & 2 & & \\
\hline $1890-99$ & 4 & 6 & 3 & & & & & 2 & 1 & 1 & 4 & 5 \\
\hline $1900-09$ & 2 & 3 & 3 & 1 & & & & 2 & 1 & 1 & 2 & 4 \\
\hline $1910-19$ & 5 & 3 & & 1 & 2 & 2 & 3 & 2 & & 5 & 5 & 2 \\
\hline $1920-29$ & 20 & 6 & 4 & 2 & 1 & 1 & 4 & 3 & 2 & 4 & 7 & 9 \\
\hline $1930-39$ & 11 & 4 & 3 & 1 & & 3 & 1 & & 3 & 2 & 2 & 3 \\
\hline $1940-49$ & 4 & 5 & & 3 & 2 & & & 3 & 1 & 3 & & 4 \\
\hline $1950-59$ & 5 & 5 & 1 & 2 & 2 & 1 & 2 & 5 & 4 & 2 & 4 & 3 \\
\hline $1960-69$ & 13 & 9 & 3 & 2 & 1 & 2 & & 1 & 1 & 6 & 17 & 14 \\
\hline $1970-79$ & 11 & 6 & 2 & & 1 & & & 1 & 1 & 4 & 4 & 14 \\
\hline $1980-89$ & 5 & 2 & & 1 & & 1 & 2 & 1 & & 4 & 1 & 2 \\
\hline $1990-99$ & 6 & 6 & & & 1 & 1 & & 1 & 2 & 1 & 1 & 4 \\
\hline Total & 123 & 80 & 29 & 19 & 12 & 12 & 18 & 25 & 28 & 54 & 71 & 107 \\
\hline
\end{tabular}


Table 2 shows the monthly distribution of these events. As is to be expected, the three winter months of December, January and February account for over half the annual total, with November contributing a further 12 percent. The probability of a storm event being experienced outside these four months is equivalent to a frequency of one year in three. May and June are particularly devoid of storms, providing only four percent of the annual total. These are also the driest months in eastern Ireland and clearly depression activity is considerably reduced on average. In contrast to the relatively quiescent spring period, however, the autumn months of September-November show a much higher incidence, with 26 percent of all storms occurring at this time. The reasons for this relate partly to the intensification of cyclogenesis which can occur on occasion at this time of year due to the absorption of the remnants of hurricanes from the western tropical Atlantic into disturbances which subsequently reach Ireland. The principal cause of enhanced autumnal frequencies is however most likely to relate to the higher sea surface temperatures which prevail in the North Atlantic at this time and which result in additional energy transfer to disturbances being achieved by comparison with the spring period.

Also apparent in Table 2 is the reduced incidence of storm reports in the nineteenth century, particularly during the summer months. Some of this relates to the different sources employed; but it is likely that some relatively quiescent decades were experienced. Dixon (1959), for example, lists very few storms for Dublin prior to the 1890 s and claims that "the 1880 's had nothing noteworthy. The 1890 s had extremes of all kinds, including gales". In support of this, Roche (1993) documents 57 shipwrecks off the Wexford coast during the $1890 \mathrm{~s}$ - one of the highest decadal totals for that coast in the steamship era - though substantial numbers of shipwrecks are also noted by him in most decades of the nineteenth century.

\section{No. of Storms per Decade 1715-1999}

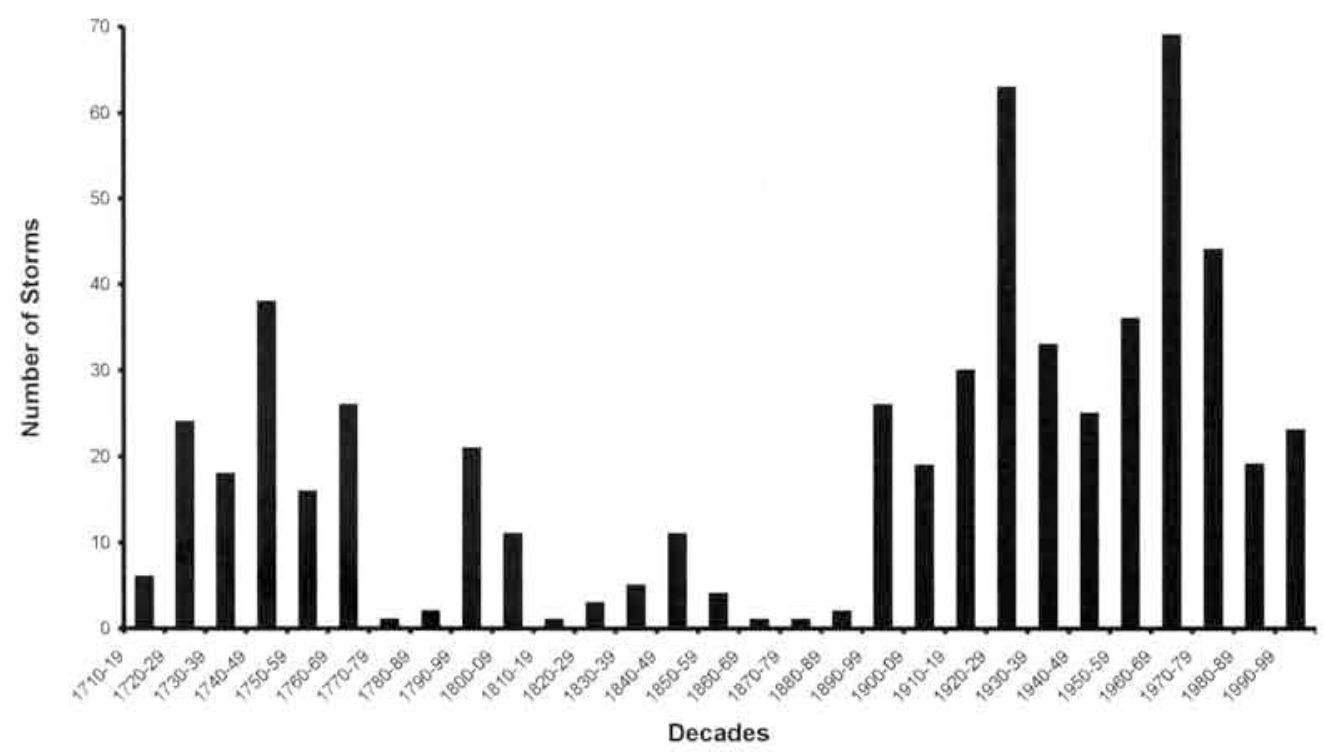

Figure 3: Storm frequency at Dublin 1715-1999 as inferred from documentary sources. 
Figure 3 displays the decadal incidence of storms as established from the documentary record. While its reliability undoubtedly increases as the present day is approached, step changes in frequencies do not appear to coincide with changes in the major sources employed. The early part of the record from the early eighteenth century until the second decade of the nineteenth century is clearly a time of enhanced storm activity. Given that this was a time when the resolution of the sources was poorer, it may be safely assumed that storm frequency during this interval was probably at least as high as during the latter half of the twentieth century. The disturbed climates of this time correspond with the period of global cooling known as the Little Ice Age and this episode is known to have been accompanied by increased storminess in many parts of Europe. It was a time of greatly increased coastal flooding, of blowing sand that blocked harbours and buried farms, and of a series of particularly vicious storms. These included the 'Defoe' storm of 1703 and also encompassed the Great North Sea storms of 1791 and 1792 when gusts at an altitude of $500 \mathrm{~m}$ above the Shetlands were estimated by Lamb (1988) at $150+/-30$ knots. After a relative lull in the mid-nineteenth century, the 1890s signal a return to storminess in Ireland. The 1920s and 1960s stand out as peak years in the documentary record, a phenomenon which is confirmed in the instrumental record.

\section{Storms: the Instrumental Record}

A total of 179 occurrences of wind gusts over 58 knots $(30 \mathrm{~m} / \mathrm{s})$ were identified by inspection of the instrumental records from Dublin from 1903 to end 1999. The value of 58 knots was chosen as a criterion since it corresponds with the mid range of Force 11 on the Beaufort Scale and is a speed at which widespread structural damage may be expected. From 1941 onwards the readings were obtained from Dublin Airport. Observations at the Airport are made at a height of 12 metres and it was not considered necessary to adjust them to correspond to the standard 10m height (Logue, 1989). Measurements before 1945 were obtainable only from a Robinson Cup anemometer on the East Pier, Dun Laoghaire. This is an over-exposed site, even though cup anemometers tend to under record high gusts by comparison to the Dines pressure recorder. There is no satisfactory conversion agreed for cup anemometer data. The site is considerably more exposed than at the Airport and this should be borne in mind when interpreting the data. Notwithstanding this, the data appear to corroborate the documentary sources quite well.

Table 3 shows the expected concentration of high wind events into the three winter months, with over 60 percent of occurrences during the December-February period. This is higher than in the documentary record and suggests that rather fewer storms outwith the main winter period are a feature of the present century. The decadal trend (Figure 4), while distorted somewhat by the data from the over-exposed Dun Laoghaire anemometer, nevertheless agrees well with the documentary reconstruction in Figure 3. Clearly there is overcounting of storms on the documentary record, thought the decade-to-decade changes in frequency are much more in agreement with the instrumental record trends. Using the documentary reconstruction to guide interpretation of the match between the two instrumental data sources employed, it seems reasonable to conclude that the 1920,1960s and 1990s were probably quite comparable in their storm frequencies in eastern Ireland. They were certainly the windiest decades of the twentieth century and probably the windiest decades since the 1740 s in eastern Ireland. 
Table 3: Number of days with gusts over 58 knots $(30 \mathrm{~m} / \mathrm{s})$ at Dublin 1903-1999.

\begin{tabular}{lrrrrcccccccc}
\hline Decade & Jan & Feb & Mar & Apr & May & Jun & Jul & Aug & Sep & Oct & Nov & Dec \\
\hline $1903-09$ & 3 & 7 & 3 & & 3 & & & & & & 1 & 1 \\
$1910-19$ & 1 & 2 & 3 & & & 1 & & 1 & 3 & 4 & 7 \\
$1920-29$ & 16 & 1 & 1 & 1 & 1 & & 1 & 2 & 4 & 6 & 7 \\
$1930-39$ & 6 & 3 & & & & 1 & & & 2 & 2 & 2 \\
$1940-49$ & 1 & 1 & & 2 & & & 1 & & & 2 \\
$1950-59$ & 1 & 1 & & & & & 1 & 2 & 4 & 5 \\
$1960-69$ & 5 & 4 & & 2 & & & & 1 & 1 & 3 & 1 \\
$1970-79$ & 5 & 1 & & & & & & 1 & \\
$1980-89$ & 3 & 2 & 2 & 1 & & & & & 1 & 5 \\
$1990-99$ & 7 & 5 & 2 & & & & & & & 1 & \\
\hline
\end{tabular}

Notes:

(i) Prior to 1945 data from Dun Laoghaire pier are used. These are strictly non-comparable with the later data from Dublin Airport.

(ii) The location of the measurements at Dublin Airport was changed in 1994.

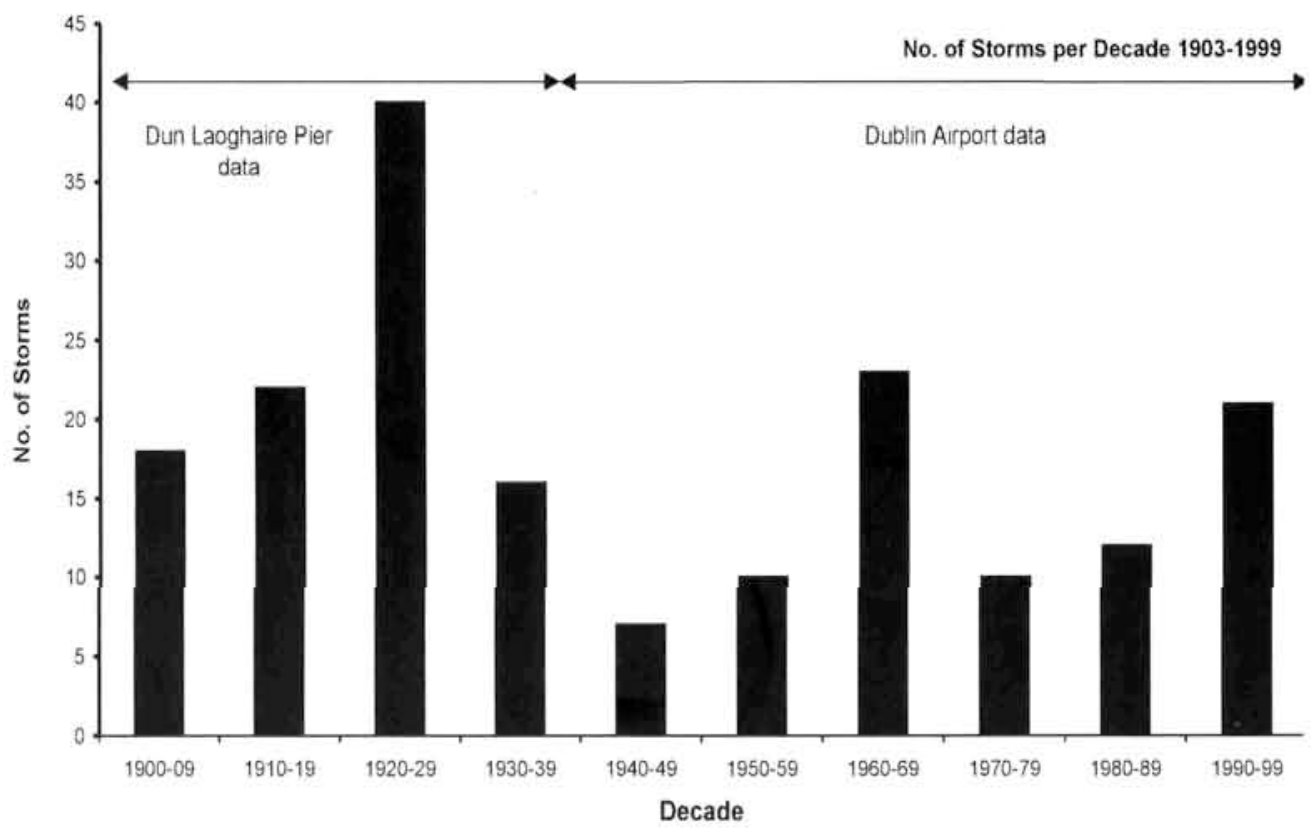

Figure 4: Storm frequency at Dublin 1903-1999 as inferred from instrumental sources.

\section{Synoptic Considerations and Conclusions}

The global warming of the early twentieth century was not as pronounced in Ireland as elsewhere in Europe. As it reached its peak in the 1930s and 1940s it was accompanied by a 
tendency for increased westerliness and decreased anticyclonic blocking in the circulation over the eastern Atlantic. The peak frequency of westerly days in the vicinity of Ireland was in the 1920s with a sharp decline from the 1950s until the 1990s when westerly frequencies increased once again (Mayes, 1991). In eastern Ireland, westerly-dominated winters equate with mildness and storminess, and the warmest run of winters during the first half of the twentieth century at the Phoenix Park in Dublin came in the 1920s.

An objective classification of synoptic type has been developed by Jones et al. (1993) to provide continuity to the well-known register developed by Lamb (1972). Taking the cyclonic categories in this as a whole provides a crude measure of how freely Atlantic depressions embedded in the westerly circulation were moving across Ireland over a particular period. In Figure 5 the frequencies of cyclonic types are plotted against storm frequencies for the Dublin region for the last century. Notwithstanding the difficulties referred to earlier in the first four decades by the use of the cup anemometer data, a close relationship is apparent between cyclonicity and storm frequencies. Storm frequencies appear to increase in decades when an increased incidence of cyclonic synoptic circulation types occur and vice-versa. Further work is however required to elaborate on this relationship which contradicts Lamb's (1988) contention that storminess in the North Sea appeared to increase in decades when blocking anticyclones were more prevalent.

A cursory examination of storm tracks does not suggest that any significant changes have taken place over the interval studied with a track just north of Ireland being the preferred trajectory for the most damaging storms in eastern Ireland. The tracks of six of the most severe storms are mapped in Figure 6. Though it may be coincidental, none of these severe storms actually passed across the landmass of Ireland to any significant extent. Perhaps the cutting off of the oceanic supply of water vapour may have a damping effect. Frictional drag on winds as well as the mid-winter thermal contrast between land and ocean (approximately $4^{\circ} \mathrm{C}$ ) may also be instrumental in inhibiting the most severe storms when they cross Ireland.

Finally, an examination of the typical synoptic situation producing severe storms in Ireland confirms that it is most often a rapidly developing secondary depression that does the damage. A primary depression, slow moving or stationary in the vicinity of Iceland anchors the airflow and acts as the generator for a rapidly moving wave disturbance. Such a quasistationary depression in the vicinity of Iceland is common in midwinter. The 'Icelandic Low' is both a thermal response to the North Atlantic Drift and also a dynamic response to the perturbations induced in the upper westerly airflow as the jetstreams cross the Western Cordillera of North America. The 1997 Christmas Eve storm in the Dublin area which produced the highest wind gust of the decade at Dublin Airport ( $76 \mathrm{knots} / 39 \mathrm{~m} / \mathrm{s}$ ) typified this process of explosive growth of a wave depression. Further work is however required to quantify how many severe Irish storms have originated in this way. One of the intriguing research questions related to this is whether the present 'secondary-low' mechanism has always been dominant. Lamb (1991) suggests that the passage of deeper, larger-scale features at a greater distance may have been a more frequent occurrence in the eighteenth and early nineteenth centuries. Finally, further work is required to ascertain what role sea surface temperature changes may play in Irish storm climatology. This is needed to clarify whether the conditions for cyclogenesis are likely to alter in the North Atlantic as global climate changes take root and the amount of energy that can be liberated as latent heat of condensation in the vicinity of Ireland increases. 
Storm Frequencies in Dublin and Cyclonic Circulation Frequencies

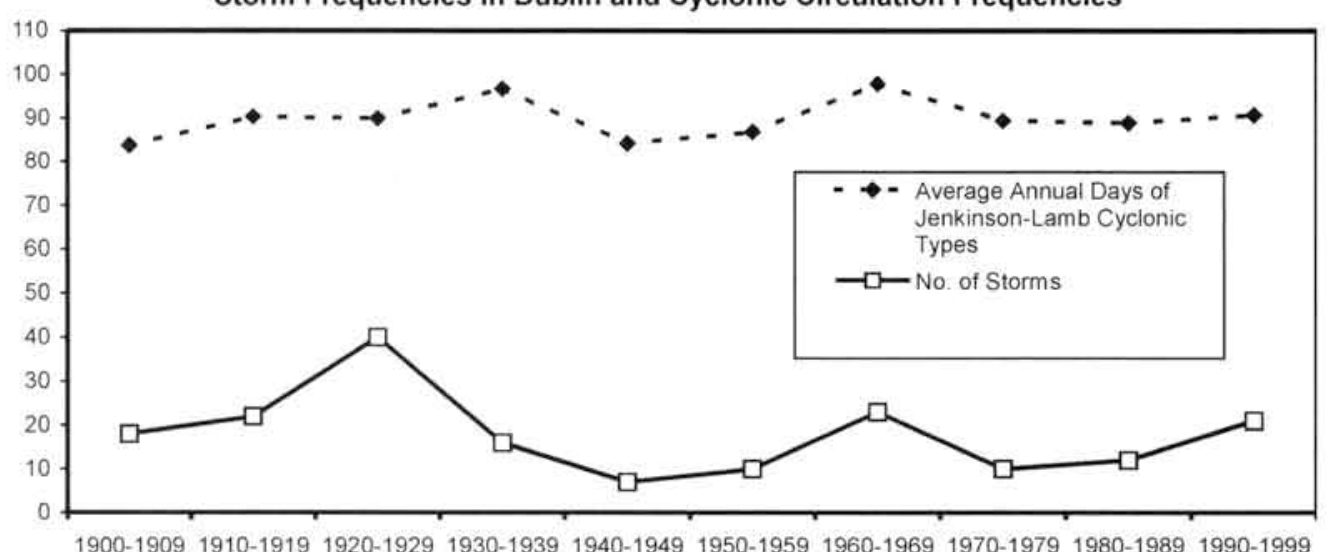

1900-1909 1910-1919 1920-1929 1930-1939 1940-1949 1950-1959 1960-1969 1970-1979 1980-1989 1990-1999

Decade

Figure 5: Mean anmual days with Jenkinson-Lamb Cyclonic Circulation categories and Decadal storm. Frequencies at Dublin Airport (Dun Laoghaire Pier prior to 1941).

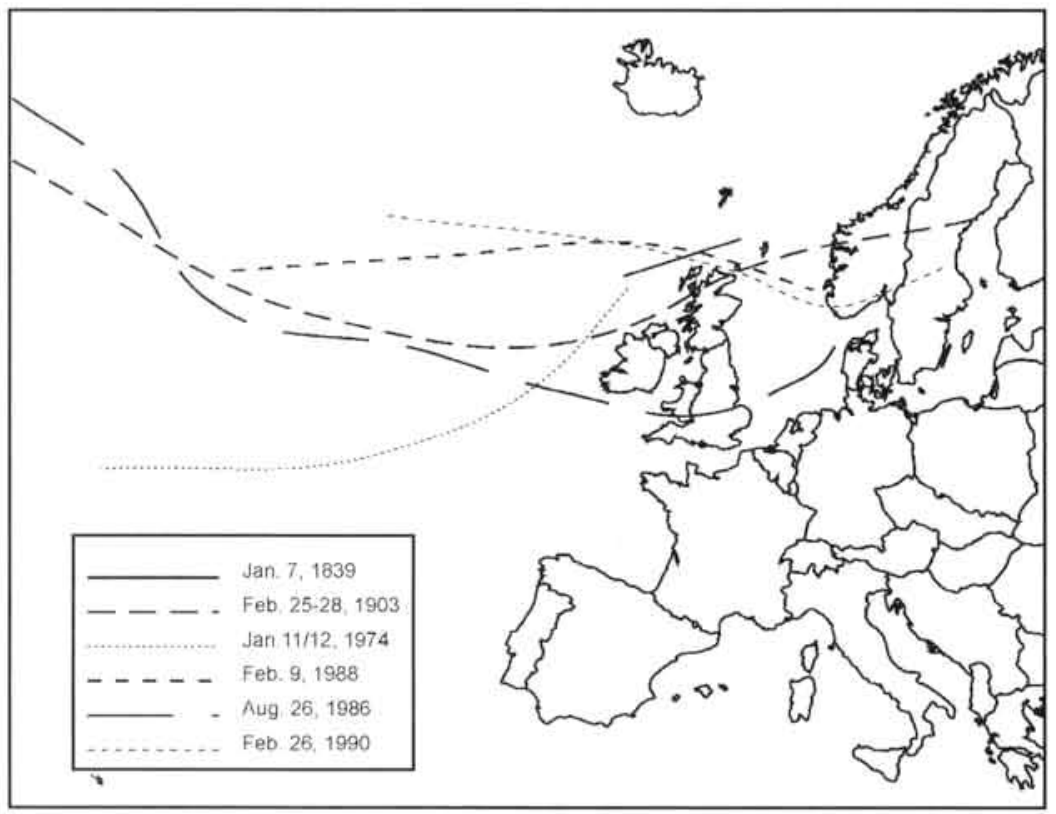

Figure 6: Trajectories for six of the most severe storms in eastern Ireland.

\section{Acknowledgements}

The author wishes to acknowledge the assistance of Janet Murray in the analysis of newspaper archives, and of Dennis Fitzgerald, Climatology Division, Met Eireann in the provision of meteorological data. 


\section{References}

BRITTON, C.E. (1937) A meteorological chronology to AD 1450. Geophysical Memoir No. 70. London: Meteorological Office.

DEFOE, D. (1704) The Storm. London.

DIXON, F.E. (1959) Weather in old Dublin, Dublin Historical Record, 15(3), 65-73.

GULEV, S.K. and HASSE, L. (1999) Changes of wind waves in the North Atlantic over the last 30 years, International Joumal of Climatology. 19, 1091-1117.

HAMMOND, J.M. (1990) Storm in a Teacup or Winds of Change, Weather, 45(12), 443-47.

HURRELL, J.W. (1995) Decadal trends in the North Atlantic Oscillation: regional temperatures and precipitation, Science, 269, 676-9.

IRISH INSURANCE FEDERATION (1999) Personal communication.

JONES, P.D., HULME, M. and BRIFFA, K.R. (1993) A comparison of Lamb circulation types with an objective classification derived from grid-point mean-sea-level pressure data. International Journal of Climatology, 13, 655-64.

LAMB, H.H. (1972) British Isles weather types and a register of the daily sequence of circulation patterns, 1861-1971. Geophysical Memoir No. 116. London: HMSO Meteorological Office.

LAMB, H.H. (1988) Weather: Climate and Human Affairs. London: Routledge.

LAMB, H.H. (1991) Historic Storms of the North Sea, British Isles and North-west Europe. Cambridge: Cambridge University Press.

LAMB, H.H. and WEISS, I. (1979) On recent changes in the wind and wave regime of the North Sea. and the outlook. Fachliche Mitteilungen 194, (Geophys. Dienst der Bundeswehr). TrabenTrarbach (Amt für Wehrgeophysik).

LINACRE, E. (1992) Climate Data and Resources. London: Routledge.

LOGUE, J.J. (1989) The estimation of extreme wind speeds over standard terrain in Ireland. Technical Note 51. Dublin: Met Éireann.

LOZANO, 1. (1999) Coastal processes and storm climatology in Ireland: understanding the globat system. Paper presented at the Conference of Irish Geographers, Dublin City University, May 1999.

MAYES, J. (1991) Regional airflow patterns in the British Isles, International Journal of Climatology. $11,473-91$.

MITCHELL, J., MANABE, S., MELESHKO, V. and TOKIOKA, T. (1992) Equilibrium Climate Change - and its Implications for the Future, In: Houghton, J. et al. (eds) Climate Change: the IPCC Assessment. Cambridge: Cambridge University Press, 131-72.

MURPHY, J.M. and MITCHELL, J.F. (1995) Transient response of the Hadley Centre coupled oceanatmosphere model to increasing carbon dioxide. Part II, spatial and temporal structure of the response, Journal of Climate, 8, 57-80.

PAGE, B. (1997) Modelling insurance losses due to winter windstorms in Europe. Paper presented at the Summer Meeting of the Association of British Climatologists, September 1997, Derby, UK.

ROCHE, R. (1993) Tales of the Wexford Coast. Enniscorthy: Duffry Press.

RUTTY, J. (1772) Natural History of the County of Dublin. Dublin.

SCHINKE, H. (1993) On the occurrence of deep cyclones over Europe and the North Atlantic in the period 1930-1991. Beitrage zur Physik der Atmosphare, 66, 223-37.

SHIELDS, L. and FITZGERALD, D. (1989) The 'Night of the Big Wind' in Ireland, 6-7 January 1839, Irish Geography, 22(1), 31-43.

WILDE, W. (1851) 185/ Census of Ireland. Part 5, Volume 1. Dublin. 